
About IJMA [last updated July, $\left.1^{\text {st }}, 2021\right]$

$\checkmark$ International Journal of Medical Arts is the Official Journal of the Damietta Faculty of Medicine, AlAzhar University, Egypt

$\checkmark$ It is an International, Open Access, Double-blind, Peer-reviewed Journal

$\checkmark$ Published four times a year

$\checkmark$ The First Issue was published in July 2019

$\checkmark$ Published under the following license: Creative Commons Attribution-ShareAlike 4.0 International Public License (CC BY-SA 4.0). It had updated from the Creative Commons license [CC BY] in volume 2, Issue 4, October 2020 About IJMA

$\checkmark$ The Egyptian Knowledge Bank hosts the web site of IJMA

$\checkmark$ The Egyptian Knowledge Bank supports IJMA

$\checkmark$ IJMA follows the regulations of the International Committee of Medical Journal Editors

$\checkmark$ IJMA is indexed in the "Directory of Open Access Journals" [15 January 2021].

$\checkmark$ IJMA is indexed in JGate [29-6-2021]

$\checkmark$ IJMA is a member of the International Society of Managing and Technical Editors

$\checkmark$ Listed in "Index Copernicus", "Publons", "Academic resource index [ResearchBib]", "Electronics journal library", "Eurasian Scientific Journal Index", and "Citefactor"

$\checkmark$ IJMA introduced to the search engine [BASE] through DOAJ
Click image to reach the page

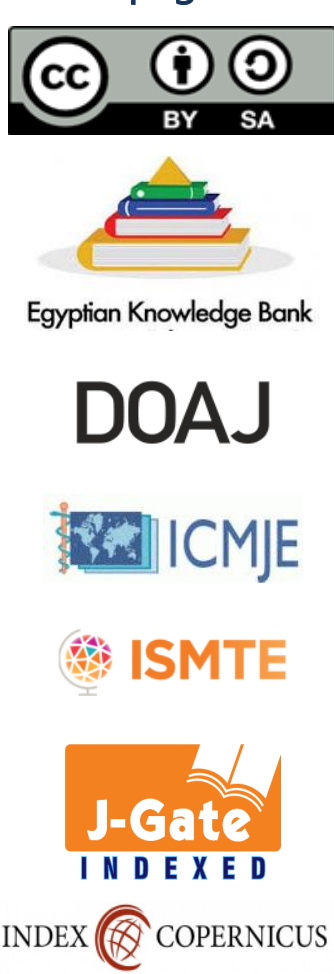

publons

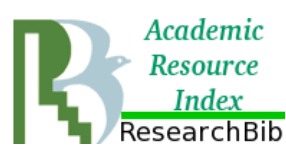

\section{EZ3 \\ .}

ESJII

CiteFactor

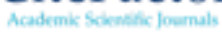

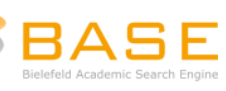




Available online at Journal Website
https://ijma.journals.ekb.eg/
Main subject [Otorhinolaryngology; Microbiology]

Original Article

\title{
The Impact of Adenoid Hypertrophy on Pediatric Chronic Maxillary Sinusitis
}

\author{
Mohammad Mahmoud Fatthy Ramadan [1]; Walaa Mohamed Omar Ashry [2] \\ ${ }^{1}$ Department of Otorhinolaryngology, Damietta Faculty of Medicine, Al-Azhar University, Egypt. \\ 2 Department of Microbiology and Immunology, Damietta Faculty of Medicine, Al-Azhar University, Egypt. \\ Corresponding author: Mohammad Mahmoud Fatthy Ramadan \\ Email: mramadanent@domazhermedicine.edu.eg \\ Submission date: April 10, 2021; Acceptance date: July 01, 2021 \\ DOI: $10.21608 /$ ijma.2021.186021
}

Background: The hypertrophied adenoids lay a role in rhinosinusitis, which is not fully unknown. The present view proposed that the hypertrophied adenoids perform as a bacterial pool and restricts the nasal mucociliary clearance. Obstructive adenoids may lead to stasis of nasal secretions with subsequent infection.

Aim of the Work: The current work aimed to assess the impact of adenoid enlargement on pediatric chronic maxillary sinusitis [PCMS].

Patients and Methods: This study included 60 Children. The size of adenoid was graded through endoscopic examination. The Clemens grading system was used. Paranasal sinuses were radiologically investigated by computerized axial tomography scan. The radiological and endoscopic data were correlated. Additionally, all adenoid samples were cultivated for bacteriological growth.

Result: The highest incidence of adenoid hypertrophy was seen in the age group 3-6 years old [60\%], with similar male to female affection rate [1:1]. The positive computed tomography [CT] scan findings among children with hypertrophied adenoid were [55\%]. The highest incidence of positive CT findings was found in grade-III adenoids, which is the highest grade of size [33.3\%]. Adenoidectomy was performed for all patients and specimens were examined for bacteriological growth. $20 \%$ of adenoid tissue had multiple growth and $80.0 \%$ showed single organism. The frequency of isolated organism were H. Influenzae, S. Pneumoniae, S. Pyogenes, S. Aureus and Methicillin Resistant Staphylococcus Aureus.

Conclusion: The endoscopically graded adenoid hypertrophy is significantly correlated to positive CT scan signs of rhinosinusitis in children. Isolation of bacteria from adenoid tissue supports the inflammatory mechanism of adenoid in pathogenesis of rhinosinutis in addition to its obstructive action. Early initiation of empirical antibiotic therapy is crucial and adenoidectomy provides a cure for adenoid hypertrophy and rhinosinusitis.

Keywords: Pediatrics; Chronic Maxillary Rhinosinusitis; Adenoid Hypertrophy; Computerized Axial Tomography.

This is an open-access article registered under the Creative Commons, ShareAlike 4.0 International license [CC BY-SA 4.0] [https://creativecommons.org/licenses/by-sa/4.0/legalcode. 


\section{INTRODUCTION}

The normal function of paranasal sinuses depends on normal mucosal secretions, transported via patent ostia by the mean of normal mucociliary clearance [1]. There are multiple factors that share in the pathogenesis of chronic rhinosinusitis [CRS], including retention of secretions in the paranasal sinuses by mechanical block of the sinus ostium due to anatomic abnormalities, such as allergic or inflammatory edema, deviated nasal septum concha bullosa, polyps etc. Also sinusitis can be developed due to impairment of mucociliary clearance mechanism as in primary ciliary dyskinesia or cystic fibrosis, and hypertrophied adenoids [2].

Adenoid hypertrophy $[\mathrm{AH}]$ is a very common medical illness in the pediatrics and adolescents, due to inflammation of chronic nature that leads to the adenoid lymphoid tissue proliferation ${ }^{[3]}$. $\mathrm{AH}$ is the primary etiology of pediatric nasal obstruction ${ }^{[4]}$.

It had been reported that, adenoids have a significant pathogenetic effect on the development of pediatric CRS in children < 12 years ${ }^{[5]}$. The association between $\mathrm{AH}$ and rhinosinusitis - in general- has been reported previously in literature, and treatment aimed at removal of adenoids or effective treatment of rhinosinusitis $[6,7]$.

The mechanisms by which adenoid tissue is contributing to sinusitis include its action as a bacterial reservoir and posterior nasal obstruction ${ }^{[8]}$.

Both of these two mechanisms are thought to impaired mucociliary clearance of the sinus cavities. Inflammatory changes in adenoid mucosal covering can cause undergo metaplastic effect with loss of cilia leading to preservation in the sinus cavity and in the adenoid pad, with microbial colonization $[8,9]$.

\section{THE AIM OF THE WORK}

The aim of the study is to estimate the impact of mechanical obstruction by the increased adenoid size on development of pediatric rhinosinusitis.

\section{PATIENTS AND METHODS}

This study included [60] Children, who presented to the Ear, Nose, Throat [ENT] Department of Al-Azhar University Hospital at New Damietta city, Egypt, by symptoms suggestive of adenoid hypertrophy [e.g., mouth breathing, snoring, and nasal airway obstruction]. This study was conducted in the period from August 2017 to January 2021. Their ages extended between three and 12 years. Any patient with other potential predisposing factors for rhinosinusitis like deviation of the nasal septum, previous sinus surgery or adenoidectomy, those under antibiotic treatment and patients below three years or older than 12 years were excluded from the study.

\section{Ethical considerations:}

The study was submitted to the Institutional Review Board for Research Ethics and Design, Damietta Faculty of Medicine, Al-Azhar University. It was investigated and approved under the number [IRB00012367-20-09-008]. Additionally, the study was explained to patient's legal guardian and an informed consent was signed. All data used only for research purposes after blinding of data. The patient's rights were assured, and treatment did not affected by the guardian decision.

The adenoid size was determined by endoscopic assessment according to Clemens et al classification [8] as depicted in Figure [1]. The grades were as the following: Grade I indicated that, the adenoid tissue occupying one third of the vertical part of the choanae. Grade II was recognized if adenoid tissue filling more than one third to about two thirds of the choanae. Grade III denotes that adenoid tissue occupying two thirds to nearly complete obstruction of the choanae. The Grade IV is assigned for complete obstruction of the choanae.

The maxillary rhinosinusitis grading was built on the radiological results of coronal CT scan Study as showed in figure [2]. Grade 0 was recognized as fully normal findings of right and left maxillary sinuses. Grade 1 stands for mucosal thickening in both right and left sinuses. Grade 2 recognized as mucosal thickening on one side and total opacification on the contralateral side. Grade 3 assigned for total opacity of both right and left maxillary sinuses.

All children underwent adenoidectomy according to surgical indications defined by American Academy of Otolaryngology/Head and Neck surgery [10]. Each adenoid was resected as a block, avoiding its break as much as possible, using a curette. The obtained specimens were washed with saline to eliminate postnasal purulent discharge on the specimen surface. The tissues were minced aseptically and inoculated onto chocolate and blood agar plates. The plates were placed into a $35.8^{\circ} \mathrm{C} \mathrm{CO}_{2}$ incubator, and the plates were incubated in an aerobic incubator. After incubation for an overnight, a microbiologist inspected the plates and the possible pathogens were isolated [11]. 


\section{Statistical analysis}

Chi square test $\left[\mathrm{X}^{2}\right]$ was used in analysis of the association between $\mathrm{AH}$ and other investigated variables in children. The level for statistical significance was set at $p<0.05$. Data were analyzed by statistical package for social science version 16 [SPSS Inc., USA]. Mean \pm SD [standard deviation] calculated for numerical data, while frequency and percentages were calculated for categorical variables.

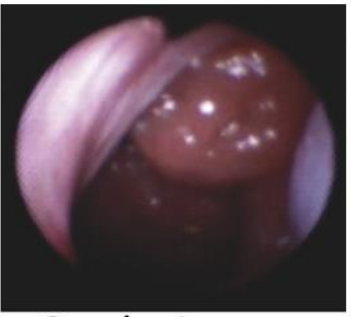

Grade 1

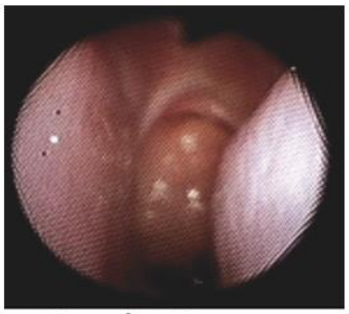

Grade 3

Figure [1]: Clemens et al classification of Adenoid hypertrophy [4]
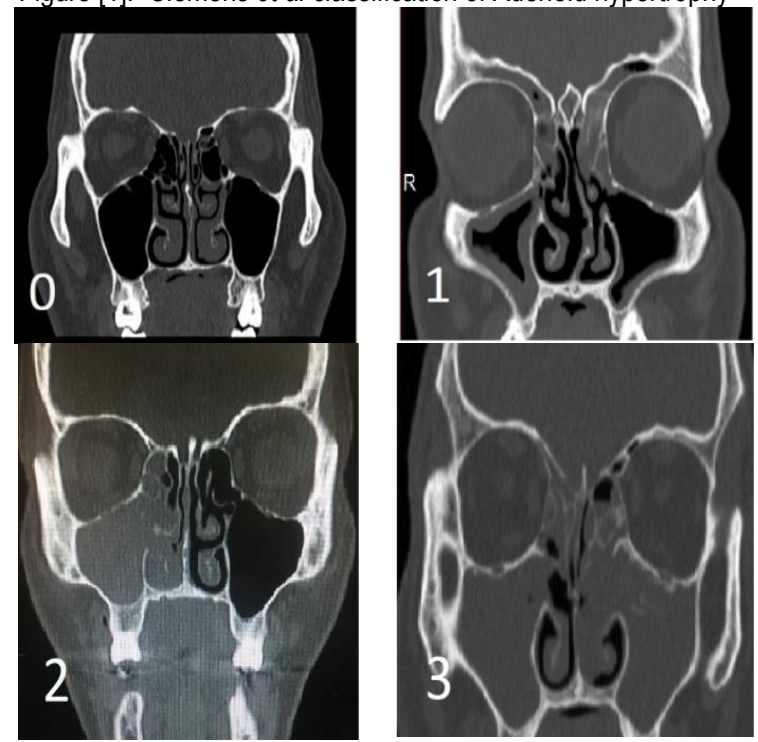

Figure [2] CT scan grading of chronic maxillary sinusitis

\section{RESULTS}

The current work included 60 children. Their mean age was 6.00 years $[6.0 \pm 2.05]$. The highest incidence of $\mathrm{AH}$ was reported the age group 3-5 years [60\%]. Thirty children [50\%] were males and the other $30[50 \%]$ were Females. The Male: female ratio was 1:1 [Table 1].
Grade III was the most common grade of adenoid size. It was detected in 20 patients [33.3\%]. On the other side, grade I was reported in 12 children [20.0\%] and represented the lowest detected grade [Table 2].

According to CT grading of maxillary rhinosinusitis, the commonest grade of maxillary rhinosinusitis was grade 0 , 27 [45.0\%], while grade 3 was the lowest grade [5.0\%] [Table 3]. Thus, the frequencies of positive findings in CT scan among patients with $\mathrm{AH}$ were [55\%].

The highest positive CT scan findings were noted in grade III adenoid, reported in 20 patients [33.3\%], while the lowest frequency of positive CT scan findings were noted in grade I adenoid, 12 patients [20\%]. In addition, there was statistically significant association between CT grading of rhinosinusitis and adenoid grade [the increase sinusitis grade, the increased adenoid grade] [Table 4].

Regarding bacteriological results, all specimens had bacterial growth, $20 \%$ of cases had more than one organism and $80.0 \%$ showed single organism. There was no significant association between bacteriological results as a whole and grade of the adenoid. The single organism showed the same statistical pattern, except significant increase of staphylococcus pyogenes in grade I when compared to other grades. The frequency of isolated organism were $H$. influenzae, S. pneumoniae, S. pyogenes, S. aureus and methicillin resistant staphylococcus aureus [Table 5].

Table [1]: Age and sex distribution among studied children

\begin{tabular}{|l|l|c|}
\hline & & Patients with adenoid hypertrophy [n=60] \\
\hline \multirow{3}{*}{ Age [year] } & $3-5 \mathrm{y}$ & $36[60.0 \%]$ \\
\cline { 2 - 3 } & $6-8 \mathrm{y}$ & $16[26.7 \%]$ \\
\cline { 2 - 3 } & $9-12 \mathrm{y}$ & $8[13.3 \%]$ \\
\cline { 2 - 3 } & Descriptive & $6.00 \pm 2.05 ; 3-12$ \\
\hline \multirow{3}{*}{ Sex } & Male & $30[50.0 \%]$ \\
\cline { 2 - 3 } & Female & $30[50.0 \%]$ \\
\hline
\end{tabular}

Table [2]: Distribution of studied children according to grading of adenoid hypertrophy

\begin{tabular}{|c|c|}
\hline Adenoid grade & Patients with adenoid hypertrophy [n=60] \\
\hline I & $12[20.0 \%]$ \\
\hline II & $15[25.0 \%]$ \\
\hline III & $20[33.3 \%]$ \\
\hline IV & $13[21.7 \%]$ \\
\hline
\end{tabular}

Table [3]: Grading of maxillary rhinosinusitis on the basis of CT scan

\begin{tabular}{|c|c|}
\hline $\begin{array}{c}\text { CT grading of } \\
\text { maxillary } \\
\text { rhinosinusitis }\end{array}$ & Patients with adenoid hypertrophy $[\mathrm{n}=60]$ \\
\hline 0 & $27[45.0 \%]$ \\
\hline 1 & $24[40.0 \%]$ \\
\hline 2 & $6[10.0 \%]$ \\
\hline 3 & $3[5.0 \%]$ \\
\hline
\end{tabular}


Table [4]: Relation between adenoid grade and CT classification of rhinosinusitis

\begin{tabular}{|c|c|c|c|c|c|c|c|c|c|c|c|}
\hline & & \multicolumn{10}{|c|}{ CT grade of rhinosinusitis } \\
\hline & & \multicolumn{2}{|c|}{$0[n=27]$} & \multicolumn{2}{|c|}{$1[n=24]$} & \multicolumn{2}{|c|}{$2[n=6]$} & \multicolumn{2}{|c|}{$3[n=3]$} & \multicolumn{2}{|c|}{ Total $[n=60]$} \\
\hline & & $\mathrm{n}$ & $\%$ & $\mathrm{n}$ & $\%$ & $n$ & $\%$ & $n$ & $\%$ & $\mathrm{n}$ & $\%$ \\
\hline \multirow{4}{*}{$\begin{array}{c}\text { Adenoid } \\
\text { grade }\end{array}$} & $\mathrm{I}$ & 7 & $25.9 \%$ & 5 & $20.8 \%$ & 0 & $0.0 \%$ & 0 & $0.0 \%$ & 12 & $20.0 \%$ \\
\hline & II & 10 & $37.0 \%$ & 2 & $8.3 \%$ & 3 & $50.0 \%$ & 0 & $0.0 \%$ & 15 & $25.0 \%$ \\
\hline & III & 6 & $22.2 \%$ & 13 & $54.2 \%$ & 0 & $0.0 \%$ & 1 & $33.3 \%$ & 20 & $33.3 \%$ \\
\hline & IV & 4 & $14.8 \%$ & 4 & $16.7 \%$ & 3 & $50.0 \%$ & 2 & $66.7 \%$ & 13 & $21.7 \%$ \\
\hline
\end{tabular}

Table [5]: Microbial isolates from adenoid tissue in relation to adenoid grade

\begin{tabular}{|c|c|c|c|c|c|c|c|}
\hline & & Total & Grade I & Grade II & Grade III & Grade IV & P value \\
\hline \multirow{2}{*}{$\begin{array}{c}\text { Isolate } \\
\text { type }\end{array}$} & Single & $48[80.0 \%]$ & $8[66.7 \%]$ & $14[93.3 \%]$ & $16[80.0 \%]$ & $10[76.9 \%]$ & 0.38 \\
\cline { 2 - 8 } & Multiple & $12[20.0 \%]$ & $4[33.3 \%]$ & $1[6.7 \%]$ & $4[20.0 \%]$ & $3[23.1 \%]$ & \\
\hline H. influenzae & $22[36.7 \%]$ & $5[41.7 \%]$ & $6[40.0 \%]$ & $6[30.0 \%]$ & $5[38.5 \%]$ & 0.89 \\
\hline \multicolumn{2}{|c|}{ S. pneumoniae } & $18[30.0 \%]$ & $4[33.3 \%]$ & $2[13.3 \%]$ & $7[35.0 \%]$ & $5[38.5 \%]$ & 0.43 \\
\hline S. pyogenes & $16[26.7 \%]$ & $6[50.0 \%]$ & $4[26.7 \%]$ & $5[25.0 \%]$ & $1[7.7 \%]$ & $0.25^{*}$ \\
\hline \multicolumn{2}{c|}{ S. aureus } & $13[21.7 \%]$ & $2[16.7 \%]$ & $3[20.0 \%]$ & $4[20.0 \%]$ & $4[30.8 \%]$ & 0.83 \\
\hline \multicolumn{2}{c|}{ MRSA } & $5[8.3 \%]$ & $0[0.0 \%]$ & $1[6.7 \%]$ & $3[15.0 \%]$ & $1[7.7 \%]$ & 0.33 \\
\hline
\end{tabular}

MRSA: Methicillin resistant staphylococcus aureus

\section{DISCUSSION}

In children with $\mathrm{AH}$ and $\mathrm{CRS}$, the indication to carry out at first a simple adenoidectomy attributed to the robust association between $\mathrm{AH}$ and CRS [12, 13]. The association between $\mathrm{AH}$ and $\mathrm{CRS}$ was proposed in different studies. Some are based on endoscopic assessment of adenoid volume ${ }^{[14]}$, on the same bacterial isolates from adenoid and nasal sinuses [15-18], on the good response on CRS after adenoidectomy [5, 19], on specific immunologic shared characteristics [20-22] and on radiological data [23]. These variations reflected the trial to confirm the association, and these studies reflected the multifactorial relationship between the two conditions. Additionally, it warrants continuous research to explore different aspects of the disease in different ethic groups.

The age of maximum incidence of $\mathrm{AH}$ was seen in 3-5 years age group. The mean age in the current work was 6 years. These findings could be explained by the rapid growth of lymphoid tissue at this age, associated with higher upper respiratory tract infection [24, 25]. Similar results are reported by Yaseen [26] from Iraq, who reported that $60 \%$ of 150 investigated children were from the age group 3-5 years. However, Shin et al. [11] reported an 8.5 years as the mean age of 410 children with adenoid. This increased mean age than the current work could be attributed to a different inclusion criteria. They included children 14 years or younger, while the maximum age in the current work was 12 years. A Swedish study [27] reported that adenoidectomy is common in children younger than 10 years old, with a peak at 3 years of age. Another study reported on a huge number of children $[n=20,599]$ with a mean age of 7.4 years and $67 \%$ were boys. They added, the age group of $3-$ to 5 year had the highest frequency in both males and females with significant increase in males than females [28]. There was similar sex distribution of adenoids with rhinosinusitis [Male to Female ratio was 1:1]. This is different than previous studies described a higher incidence in boys than girls $[29,30]$.

In the current work, $33.3 \%$ were of grade III on the adenoid side classification scale and the lowest grade was grade I [20\%]. The CT for rhinosinusitis revealed positive findings among $55 \%$ of studied children and the majority [40.0\%] were grade I. The majority of positive CT results were of grade III adenoids followed by grade II and then grade IV. The possible explanation is that, the hypertrophied adenoid blocking the posterior choanae and interfere with the normal nasal drainage. Thus, the sinus secretions drop in a stasis state that represent a good media for bacterial growth and inevitable paranasal sinusitis.

The clinical differentiation between CRS and adenoiditis is a challenge and the use of an additional aid is mandatory. A study by Bhattacharyya et al. ${ }^{[31]}$ stated that, computed tomography $[\mathrm{CT}]$ for paranasal sinuses can differentiate 
between the two entities based on Lund-Mackay CT score. Ramadan et al. [23] also concluded that, CRS diagnosis by CT in children is critical for the initial treatment. It usually determines whether, adenoidectomy alone is a suitable and appropriate option of treatment, especially in children who have asthma. Results of the current work are comparable to that of Yaseen et al. ${ }^{[32]}$ who reported that, an endoscopic evaluation revealed that, grade III of adenoid size was the commonest grade [33.3\%] and the least was grade I [13.3\%].

As in the current work, different previous studies appreciated the role of endoscopy in assessment of adenoid. They concluded that nasopharyngoscopy is the gold standard in the assessment of AH [33-34]. Suzuki et al. [35] reported a $51.7 \%$ incidence of rhinosinusitis in children who underwent adenoidectomy. Shin et al. [11] showed an incidence rate of $53.2 \%$. These data are in line with the current work.

Results of bacterial isolates are comparable to previous studies in literature. Bernstein et al. ${ }^{[17]}$ showed that in $89 \%$ of cases with chronic rhinosinusitis, the same bacterial colonies were isolated from the swab from adenoids. Haemophilus influenzae, S. pneumoniae, and Moraxella catarrhalis were the frequent isolated bacteria isolated. They excluded the $S$. aureus due to high rate of nasal colonization. Here, we not excluded it as we washed out any nasal discharge before incubation of adenoid tissue. Shin and colleagues ${ }^{[1]}$ used adenoid samples instead of swabs. They reported similar bacterial isolates as the current work [Haemophilus influenza, Streptococcus pneumonia, Streptococcus pyogenes and Staphylococcus aureus]. Lin et al. ${ }^{[13]}$ concentrates his bacteriological analysis on $\mathrm{S}$. aureus in a sample 283 Taiwanese children. They reported that, Staphylococcus aureus is present in $21.2 \%$ of adenoid specimens. They also showed that $S$. aureus was a frequent cause of $\mathrm{AH}$ and not just a simple colonization. The importance of the determination of bacteria involved in $\mathrm{AH}$ and CRS is that it helps to establish an empiric antibiotic therapy for treatment of CRS associated with $\mathrm{AH}$. This was consolidated in the study by Davcheva-Chakar et al. ${ }^{[18]}$ who tested the susceptibility of isolated microorganisms [from adenoid and sinus samples] to different antibiotics [e.g., penicillin, cephalosporine, macrolides, quinolones and others]. They reported that, H. Influenzae, S. Pyogenes, and $S$. aureus strains were susceptible to all antibiotics, except for cotrimoxazole. Mild resistance was found for $S$. pneumoniae, and Moraxella catarrhalis.

Conclusion: Maximum age incidence of adenoid hypertrophy was in 3-5 years. The adenoid grading determined endoscopically is significantly associated with increasing in positivity of CT scan findings. Isolation of bacteria from all adenoid tissue specimens augments the inflammatory role of adenoid in pathogenesis of rhinosinutis in addition to its obstructive mechanism. Initiation of empirical antibiotic therapy is crucial and adenoidectomy provides a cure for $\mathrm{AH}$ and rhinosinusitis.

Financial and Non-financial Relationships and Activities of Interest

None to be declared

\section{REFERENCES}

1. Tan R, Spector S. Pediatric sinusitis. Curr Allergy Asthma Rep. 2007 Nov;7[6]:421-6. [DOI: 10.1007/s11882-007-0064-5].

2. Brietzke SE, Shin JJ, Choi S, Lee JT, Parikh SR, Pena M, et al. Clinical consensus statement: pediatric chronic rhinosinusitis. Otolaryngol Head Neck Surg. 2014; 151[4]:542-53. [DOI: 10.1177/0194599814549302].

3. Bowers I, Shermetaro C. Adenoiditis. 2021 Jul 18. In: StatPearls [Internet]. Treasure Island [FL]: StatPearls Publishing; 2021 Jan-. [PMID: 30725616].

4. Feng X, Li G, Qu Z, Liu L, Näsström K, Shi XQ. Comparative analysis of upper airway volume with lateral cephalograms and cone-beam computed tomography. Am J Orthod Dentofacial Orthop. 2015 Feb; 147[2]:197-204. [DOI: 10.1016/j.ajodo.2014.10.025].

5. Gerber ME, Kennedy AA. Adenoidectomy with Balloon Catheter Sinuplasty: A Randomized Trial for Pediatric Rhinosinusitis. Laryngoscope. 2018; 128[12]:2893-2897. [DOI: 10.1002/lary. 27270].

6. Bulfamante AM, Saibene AM, Felisati G, Rosso C, Pipolo C. Adenoidal Disease and Chronic Rhinosinusitis in Children-ls there a Link? J Clin Med. 2019; 8[10]:1528. [DOI: 10.3390/ jcm8101528].

7. Tuncer U, Aydogan B, Soylu L, Simsek M, Akcali C, Kucukcan A. Chronic rhinosinusitis and adenoid hypertrophy in children. Am J Otolaryngol. 2004 Jan-Feb; 25[1]:5-10. [DOI: 10.1016/ j.amjoto.2003.10.003].

8. Arnaoutakis D, Collins WO. Correlation of mucociliary clearance and symptomatology before and after adenoidectomy in children. Int J Pediatr Otorhinolaryngol. 2011 Oct; 75[10]: 1318-21. [DOI: 10.1016/j.ijporl. 2011.07.024].

9. Marusiakova L, Durdik P, Jesenak M, Bugova G, Kvassayova J, Oppova D, Banovcin P. Ciliary beat frequency in children with adenoid hypertrophy. Pediatr Pulmonol. 2020; 55[3]:666673. [DOI: 10.1002/ppul.24622].

10. Schupper AJ, Nation J, Pransky S. Adenoidectomy in Children: What Is the Evidence and What Is its Role? Curr Otorhinolaryngol Rep. 2018; 6[1]:64-73. [DOI: 10.1007/ s40136-018-0190-8].

11. Shin KS, Cho SH, Kim KR, Tae K, Lee SH, Park CW, Jeong $\mathrm{JH}$. The role of adenoids in pediatric rhinosinusitis. Int $\mathrm{J}$ 
Pediatr Otorhinolaryngol. 2008; 72[11]:1643-50. [DOI: 10. 1016/j.jporl.2008.07.016].

12. Marseglia GL, Pagella F, Klersy C, Barberi S, Licari A, Ciprandi G. The 10-day mark is a good way to diagnose not only acute rhinosinusitis but also adenoiditis, as confirmed by endoscopy. Int J Pediatr Otorhinolaryngol. 2007 Apr; 71[4]: 581-3. [DOI: 10.1016/j.jporl.2006.12.003].

13. Lin CD, Tsai MH, Lin CW, Ho MW, Wang CY, Tsou YA, et al. Association of adenoid hyperplasia and bacterial biofilm formation in children with adenoiditis in Taiwan. Eur Arch Otorhinolaryngol. 2012 Feb; 269[2]:503-11. [DOI: 10.1007/ s00405-011-1704-x].

14. Wang DY, Bernheim N, Kaufman L, Clement P. Assessment of adenoid size in children by fibreoptic examination. Clin Otolaryngol Allied Sci. 1997 Apr; 22[2]:172-7. [DOI: 10.1046 jj.1365-2273.1997.00002.x].

15. Javadi Nia S, Zarabi V, Noorbakhsh S, Farhadi M, Ghavidel. Chlamydophila pneumoniae Infection Assessment in Children With Adenoid Hypertrophy Concomitant With Rhino Sinusitis. Jundishapur J Microbiol. 2014; 7 [8]: e11134. [DOI: 10.5812/ jjm.11134].

16. Cedeño EE, Ortiz-Princz D, Figueredo SA, Porro ME. Adenoid hypertrophy and chronic rhinosinusitis: Helicobacter pylori on antral lavages, adenoid tissue and salival inmunoglobuline A on pediatric patients. Int J Pediatr Otorhinolaryngol. 2016 Jan;80:82-7. [DOI: 10.1016/j.jporl.2015.11.019].

17. Bernstein JM, Dryja D, Murphy TF. Molecular typing of paired bacterial isolates from the adenoid and lateral wall of the nose in children undergoing adenoidectomy: implications in acute rhinosinusitis. Otolaryngol Head Neck Surg. 2001; 125[6]:5937. [DOI: $10.1067 / \mathrm{mhn} .2001 .120232]$.

18. Davcheva-Chakar M, Kaftandzhieva A, Zafirovska B. Adenoid Vegetations - Reservoir of Bacteria for Chronic Otitis Media with Effusion and Chronic Rhinosinusitis. Pril [Makedon Akad Nauk Umet Odd Med Nauki]. 2015; 36 [3]:71-6. [DOI: 10.1515/ prilozi-2015-0080].

19. Ramadan HH, Cost JL. Outcome of adenoidectomy versus adenoidectomy with maxillary sinus wash for chronic rhinosinusitis in children. Laryngoscope. 2008; 118[5]:871-3. [DOI: 10.1097/MLG.0b013e3181653422].

20. Qu XP, Huang ZX, Sun Y, Ye T, Cui SJ, Huang Q, et al. Expression of Innate Immunity Genes in Epithelial Cells of Hypertrophic Adenoids with and without Pediatric Chronic Rhinosinusitis: A Preliminary Report. Chin Med J [Engl]. 2015 Nov 5; 128[21]:2913-8. [DOI: 10.4103/0366-6999.168056].

21. Shin SY, Choi GS, Park HS, Lee KH, Kim SW, Cho JS. Immunological investigation in the adenoid tissues from children with chronic rhinosinusitis. Otolaryngol Head Neck Surg. 2009; 141:91-6. [DOI: 10.1016/ j.otohns.2009.03. 023].

22. Belcher R, Virgin $F$. The Role of the Adenoids in Pediatric Chronic Rhinosinusitis. Med Sci [Basel]. 2019 Feb 25; 7[2]:35. [DOI: 10.3390/medsci7020035].
23. Ramadan HH, Makary CA. Can computed tomography score predict outcome of adenoidectomy for chronic rhinosinusitis in children. Am J Rhinol Allergy. 2014; 28[1]: e80-2. [DOI: 10.2500/ajra. 2014.28.4004].

24. Pereira L, Monyror J, Almeida FT, Almeida FR, Guerra E, Flores-Mir C. Prevalence of adenoid hypertrophy: A systematic review and meta-analysis. Sleep Med Rev. 2018; 38:101-112. [DOI: 10.1016/j.smrv.2017.06.001].

25. Brambilla I, Pusateri A, Pagella F, Caimmi D, Caimmi S, Licari A, Barberi S, Castellazzi AM, Marseglia GL. Adenoids in children: Advances in immunology, diagnosis, and surgery. Clin Anat. 2014; 27[3]:346-52. [DOl: 10.1002/ca.22373].

26. Yaseen ET. The Relationship between Adenoid Hypertrophy and Maxillary Rhinosinusitis in Children. Iraqi J Comm Med. 2011; 24 [4]: 335-338.

27. Gerhardsson H, Stalfors J, Odhagen E, Sunnergren $\mathrm{O}$. Pediatric adenoid surgery in Sweden 2004-2013: Incidence, indications and concomitant surgical procedures. Int J Pediatr Otorhinolaryngol. 2016; 87:61-6. [DOl: 10.1016/j.jporl.2016. 05.020].

28. Lee CH, Hsu WC, Ko JY, Yeh TH, Chang WH, Kang KT. Epidemiology and trend of pediatric adenoidectomy: a population-based study in Taiwan from 1997 to 2012. Acta Otolaryngol. 2017; 137[12]:1265-1270. [DOl: 10.1080/ 00016489. 2017.1357191].

29. Thomas K, Boeger D, Buentzel J, Esser D, Hoffmann K, Jecker $\mathrm{P}$, et al. Pediatric adenoidectomy: a population-based regional study on epidemiology and outcome. Int J Pediatr Otorhinolaryngol. 2013; 77[10]:1716-20. [DOI: 10.1016/j.jporl. 2013.07.032].

30. Dearking AC, Lahr BD, Kuchena A, Orvidas LJ. Factors associated with revision adenoidectomy. Otolaryngol Head Neck Surg. 2012 Jun; 146 [6]: 984-90. [DOI: 10.1177/ 0194599811435971].

31. Bhattacharyya N, Jones DT, Hill M, Shapiro NL. The diagnostic accuracy of computed tomography in pediatric chronic rhinosinusitis. Arch Otolaryngol Head Neck Surg. 2004; 130[9]:1029-32. [DOI: 10.1001/archotol.130.9.1029].

32. Yaseen ET, Khammas AH, Al- Anbaky F. Adenoid enlargement assessment by plain $\mathrm{X}$-ray \& Nasoendoscopy. Iraqi J. Comm. Med 2012; 1: 88-91.

33. Bitar MA, Birjawi G, Youssef M, Fuleihan N. How frequent is adenoid obstruction? Impact on the diagnostic approach. Pediatr Int. 2009 Aug; 51[4]:478-83. [DOI: 10.1111/j.1442200X.2008.02787.x].

34. Kubba $\mathrm{H}$, Bingham BJ. Endoscopy in the assessment of children with nasal obstruction. J Laryngol Otol. 2001 May; 115[5]:380-4. [DOI: 10.1258/0022215011907929].

35. Suzuki M, Watanabe T, Mogi G. Clinical, bacteriological, and histological study of adenoids in children. Am J Otolaryngol. 1999; 20[2]:85-90. [DOI: 10.1016/s0196-0709[99]90016-9]. 

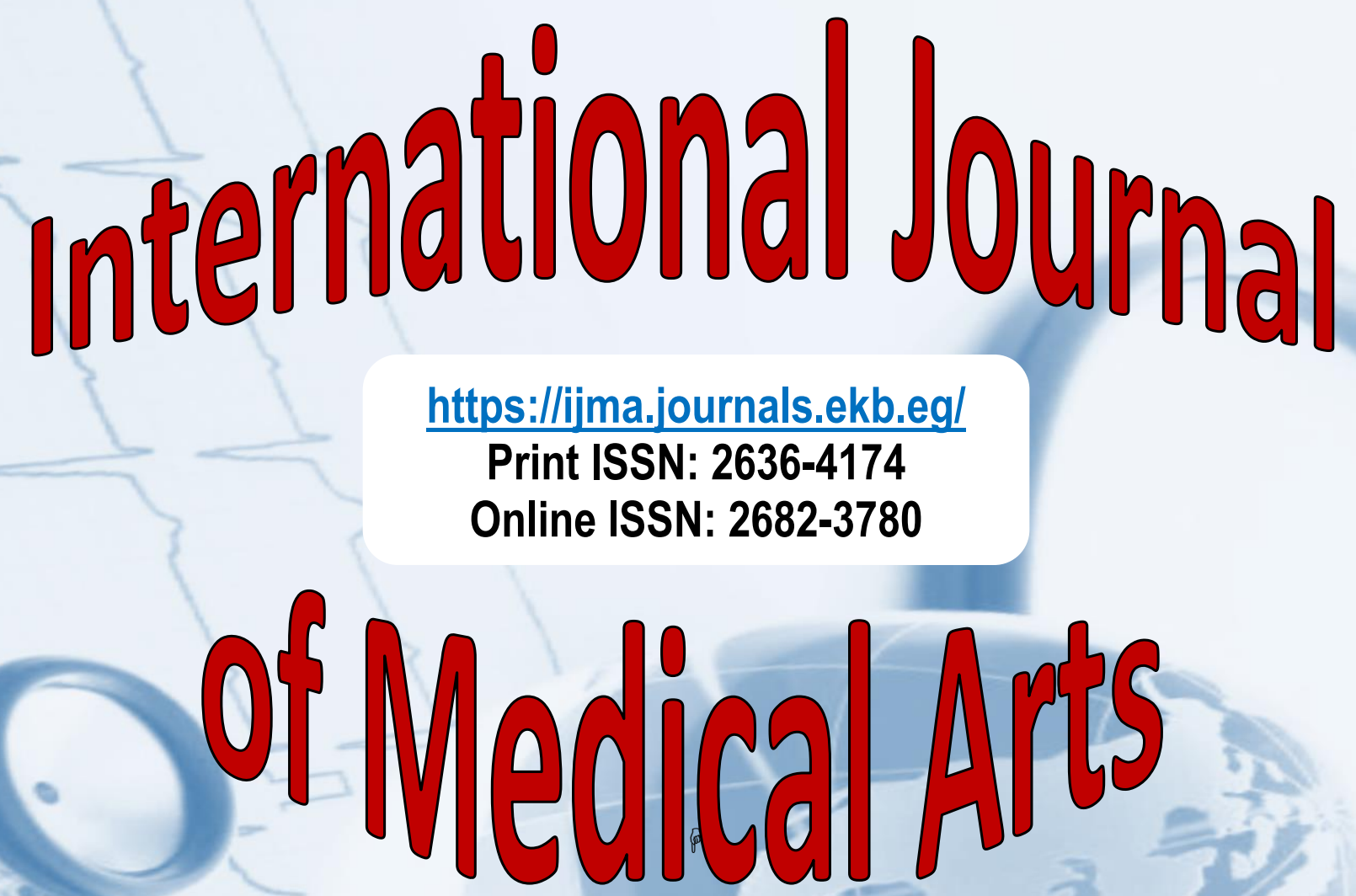